\title{
YAZILI BASINDA VE İNTERNET GAZETECILIĞGINDE KULLANILAN HABER FOTOĞRAFLARININ KARŞILAŞTIRILMASI
}

\author{
Olcay UÇAK \\ İstanbul Aydın Üniversitesi, İletişim Fakültesi, Türkiye \\ olucak@gmail.com
}

\begin{abstract}
Photograph, enter a new process in the transformation of traditional media into digital media. Thereby photograph is the most important transporter of the visual culture in the internet environment. The photograph whose area of usage continues to expand from science to industry, from communication to education become widespread more quickly by the development of technology. In media, the usage of photo offer alternative options to reporters that they can transfer meanings which they are not able to fit in the written texts. The photo's characteristic of recording events carry a meaning of the power it has got. This power, with the high-speed the photo transfer gets in the digital environment increases its importance. In this study, news photos which are used in internet course as a means of communication and expresssion will be analyzed by the method of semiotics. By comparing the photograph analysis to be made with the photo datas used in printed media, the present stage in the environment of newspaper and internet will be discussed.
\end{abstract}

Keywords: Visual Culture, New Media, News Photo, Photo Analysis.

\section{GÍRIŞ}

Geleneksel yazılı basında haberlerin oluşturulması metin ve fotoğrafin birlikte kullanımı ile kabul görürken, günümüzde haberlerin sunumunda fotoğrafın öncelik kazandığg görülmektedir. Yazılı basında fotoğrafın yazıdan sonra ya da yazının bir parçası olarak kullanılması geleneği yeni medya oluşumu ile değişmektedir. Bu değişim ile fotoğraf belirgin bir biçimde haber metinlerinden daha öncelikli bir konuma yükselmektedir. Aynı zamanda internet ortamında sayfalardaki yer sorununun göreceli olarak ortadan kalkmış olması haberlerde kullanılan görsel unsurların sayısının da artmasına neden olmaktadır. Böylece yeni medyanın gelişmesiyle, görsel unsurların egemenliğinde fotoğrafın yazıya baskın olduğu yeni bir dönüşüm süreci başlar. Bu çalışma, internet gazeteciliğinde fotoğrafın yazının önüne geçmeye başladığı bu dönüşüme dikkat çekmek ve gazete inceleme örnekleriyle bu dönüşümü ortaya koymak amacındadır.

Giderek hızlanan bu dönüşümde gerçekliğin haber görünümünde sunuluşu ve nesneleri algılama önem kazanır. Gerçekliğin önemli bir bölümünü oluşturduğu varsayılan nesneler, "algılanan" (percipienda) olarak nitelenmektedir. Bu, nesnenin algılanabilecek özelliklerinin varlığı anlamına gelir. "Algı" (percepta) ise, nesneler hakkında bireyin duyu organları tarafından edinilen verilerdir (sense-data) (Derman,1991:34). Barthes'e göre $(2009,196)$ nesne, insanın dünyayı etkilemesine, dünyayı değiştirmesine, dünyada etkin bir biçimde var olmasına yarar; nesne, eylem ile insan arasında bir tür aracıdır. Dolayısıyla fotoğraf aracılığıyla gerçeğin farklı algılanışlarına olanak tanınır. Susan Sontag'ın "Fotoğraf kaçınılmaz olarak gerçekliğe belli bir şekilde tepeden bakmayı gerektirir." (Sontag,2008: 100), görüşü saklı kalsa da fotoğraf medyanın kendi gerçekliğini yaratma unsurlarından biri olmaya devam eder.

Günümüz dünyasında imgelerle ifade edilen yeni bir anlayışın egemen olduğu, görsel kültürün yazılı kültüre tercih edildiği yeni bir anlayış dikkat çekmektedir. $\mathrm{Bu}$ anlayış iletişimin diğer dallarında olduğu gibi yazılı basında ve onun yeni uzantısı olan internet 
gazeteciliğinde de farklılıklara yol açmaktadır. Dolayısıyla medyanın en önemli görsel unsurlarından biri olan fotoğrafi anlamak ve çözümlemek gerçeğe ulaşmada eskisinden çok daha fazla önem kazanmaktadır.

Fotoğraf kullanımında yararlanılan görsel söylemin çözümlenmesinde en geçerli yöntemlerden biri Görsel Göstergebilim Yöntemi olarak kabul edilmektedir (İnceoğlu\&Çomak, 2009:289). Bu nedenle çalışmada Groupe $\mu$ 'nün görsel söylem çözümleme yöntemi uygulanmıştır. Groupe $\mu$ (Grup mü olarak okunur), biçimsel kalmakla eleştirilmiş olsa da göstergebilimi bilişsel, estetik, toplumsal ve iletişimsel kaygılarla ele almıştır. Groupe $\mu$, imgenin başlı başına bir dil olup olmadığı sorusuna yanıt arar. İkonik ve plastik göstergenin iki ayrı gösterge sınıfı olarak ele alınmasını, her birinin de ayrı biçim ve içerik düzlemleri olması gerektiğini savunur. Böylece göstergenin keyfiliği ve nedenliliği olgularını yeniden ele alır (Groupe $\mu$, Traité du signe visuel, 1992, 9, akt. İnceoğlu ve Çomak, 2009:293).

Plastik Gösterge: İmgelerin plastik öğeleri, renkleri, biçimleri, kompozisyon ve doku yalnızca ikonik göstergelerin anlatımı değil, başlı başına birer gösterge olarak incelenir. Büyük plastik gösterge ailelerinin işlevleri tanımlanır. $\mathrm{Bu}$ aileler renkler, biçimler ve dokulardır. Plastik bir söylem biçimler açısından, renkler açısından, dokular ve sonra da bunların oluşturduğu bütünler açısından incelenebilir. Ayrıca bu verilerin birlikte var olduğunu, bir dizge tarafindan ortaya konulduğunu da belirtmek gerekir.

Renk: Groupe $\mu$, renklerin sıcak/soğuk ve kontrastlar olarak bölümlenebileceğini belirtir (1992:239). Bu karşıtlıklar anlam yaratmakta kullanılır. Plastik gösterge olarak renk öğesi şu kurallara bağlıdır: Her renk, anlatımın bir birimi olarak 1şık, egemenlik ölçütlerine göre belirlenir. Her renk içeriğin bir birimi olarak bir ya da birçok anlambilimsel eksende yer alır. Her renk, görsel iletide yer alan öteki renklerle bir bağıntı oluşturur. Bu bağıntılardan bazıları gerilim bazısı da denge izlenimi verir. Renkler plastik göstergenin öteki bileşenleri biçim ve dokuyla, aynı zamanda ikonik göstergeyle karşı karşıyadırlar. Bu da kimi içeriklerin öne çıkmasına, kimilerinin geriye atılmasına neden olur.

Doku: Doku da renk gibi bir yüzey niteliğidir, öğelerinin doğası, boyutu ve yinelenmesiyle belirlenir. Genellikle imgelerin iki boyutlu olduğu düşünülür. Ancak dokuya bağlı olarak çok az da olsa bir derinlikten söz edilebilir. Doku, üç boyutluluk, dokunsallık ve dişavurum izlenimi verebilir. Bir yağlıboya tablo ile dergi fotoğrafı arasında dokusal olarak önemli fark vardır. İmgelerde yalnızca doku farklılığıyla bir ayrıma gidilme olasılığı vardır (1992:70).

Biçim: Çizgi, alan, sınır, yüzey, çevre çizgisi (kontur), biçim ve fon gibi topluluğun "görsel dürtüler” diye tanımladığ algı niteliklerine bağlı olarak ortaya çıkar, bir bakıma görsel dilbilgisinin öğeleridir ve dilsel dizgedeki tümceler, sözcükler gibi kimi yapıların yerine geçerler. Sınır, alanı ikiye bölen bir çizgidir, alanların biri ya da öteki için daha üstün bir konum öngörmez.

İkonik Gösterge: İkonik göstergeler evrende bulunan nesnelerin imge düzleminde dönüştürülmüş ya da yeniden oluşturulmuş biçimidir. Groupe $\mu$ 'ye göre, bir betinin ikonik olarak değerlendirilmesinin nedeni, türünün tek örneği olmamasıdır. Böylece kendi dışındaki bir düşünceye göndermede bulunur. Alan belirginliği ve derinliği, ikonik göstergenin algilanmasında belirleyicidir. İmgenin tüm düzlemi eski ve klasik resimde, fotoğrafta olduğu gibi aynı belirginlikte verilmişse, göz bu belirginliği yalnızca yerel olarak algılar; gerisi daha silik kalır. Bu imge türünde tüm noktalar sabit bir görüntü sunar. Alan derinliği objektif seçimiyle azaltılabilir. Optik dönüşümler imgenin fiziksel niteliklerini etkilediğinden, ikonik göstegenin algılanmasını değiştirebilir. Fotoğrafçılar bunu bilir ve ışı̆̆ı, yoğunluğu ve uzamda yönelimleriyle incelerler. Görsel söylemi çözümleyebilmek için ikonik göstergelerin içerik düzlemindeki anlamlarını ve yananlamlarını ortaya çıkarmak gerekir. 


\section{FOTOĞRAFIN OKUMA BICÇIMLERİ}

Gazetelerde yer alan haber metinleri gibi fotoğraflar da mesaj niteliği taşır. Kaynak mesajın kodlandığı basın organıdır, hedef ise okuyucudur. Basında yer alan bir fotoğraf sayısız etmenler tarafından etkilenir, anlamı bu etmenlerce belirlenir. Fotoğrafın çekilmesi, seçilmesi aşamasında başlayan anlam oluşturma, hangi sayfada yer alacağı, alt yazısı, metin ve manşet ile belirlenir.

Fotoğraf okunurken bütün bu etmenler göz önünde tutulmalıdır. Basın fotoğrafına ikincil anlamlar yüklenmesi işinde yukarıda bahsedilen etmenler devreye girer. Bunun dışında poz verdirme ile fotoğrafa farklı anlamlar yüklenir. Örneğin bir politikacı olduğundan daha güven veren bir havaya kavuşturulabilir (Terzi,2006:37). Ayrıca değişik 1şık kullanımı ve çekim sonrası bilgisayar programları ile farklı etkiler yaratılabilir. Görüntü göstergebilimi, bir gazete fotoğrafının, tanıtım amaçlı bir resmin, bir görüntünün okunmasını yönlendiren uzlaşımları ortaya çıkarmayı hedefleyen bir bilim dalıdır (Gezgin,1994: 49).

Estetizmde ise fotoğraf kompozisyon olarak işlenmiştir. Bir de sözdizimi denen bir olgu vardır. Bu da fotoğrafların bir öykü oluşturacak şekilde yan yana getirilmesidir. Metin, basın görüntüsünün yan anlamlandırılmasında en önemli etkendir. Metin ya da altyazı yan anlamlara işaret eder. Ayrıca çekim açısı, makinenin bulunduğu nokta, çerçeveleme, editörce 2.kez çerçeveleme fotoğrafın anlamını etkiler.

Fotoğraflar zaman zaman tarihsel/kültürel perspektifte yer alan ya da almış görüntülere göndermede bulunabilir. Fotoğrafi izleyenin içinde bulunduğu kültürel ortam da fotoğrafın anlamının çözümlenmesinde önem taşır. Kimi zaman bazı fotoğraflar simge olabilir. İlk kullanıldıkları andaki anlamlarını yitirerek belli bir dünya görüşünün, kültürün veya bilginin aktarıcısı olabilirler (Terzi,2006:41). Renklerin kontrastı ile diğer görsel unsurlarda olduğu gibi fotoğraflar da farklı anlamlar kazanır (Ketenci ve Bilgili,2006:110). Başlıca kontrastlar, açıklık-koyuluk, sıcak-soğuk, doygunluk, komşuluk, tamamlayıcı ve alan genişliği kontrastlarından söz edilir. Sıcak-soğuk kontrastı, alev renkleri olan sarı, turuncu ve kırmızı ile; soğuk etkisi veren mavi renklerle sağlanır. Renkleri dengeye dayalı kullanmak amacıyla Gothe, renklere dikkat çekme özelliklerine göre ağırlık değeri tespit ederek bazı rakamlar vermiş, ressamlar bunu geliştirmiştir. Sarı 3, Turuncu 4, Kırmızı 6, Mor 9, Mavi 8, Yeşil 6. Örnek olarak denge için mor/sarı oranı=3/1 olur. Fotoğrafları çözümlerken belli karşıtlıklardan ve yan anlamlardan yola çıkılır. Örneğin askerlere çiçek veren çocuklar veya bir tüfeğin namlusuna takılmış çiçek gibi. Bir fotoğrafı okurken onun gerçeği ne denli yansıttığ 1 , düz ve yan anlamları, tarihsel, kültürel dağarcıktaki yeri, herhangi bir düşünceyi simgeleyip simgelemediği gibi etmenlere dikkat etmek gerekir. Fotoğraf bir iletişim arac1 olmanın yanı sıra kültürel ve toplumsal işleve de sahiptir. Her görüntünün bir anlamı vardır ve bir bilgiyi bir iletiyi taşır, aktarır veya bünyesinde bulundurur. Renkler de kullanılan topluma göre anlam kazanır. Siyah renk yas rengi iken Japonlarda onun yerine beyaz geçer. Beyaz bizim içinse saflık, temizliktir. Fotoğraf makinesinin nesneyi ya da olayı gördüğü nokta, bakış açısı gibi etmenler farklı mesajlar içerir. Görüntüyü oluşturan dilsel ve simgesel öğelerin iyi tanınması, bir fotoğrafın çözümlenmesinde kuşkusuz yararlar sağlayacaktır.

Basılı gazetelerde haber sayısı konusunda yapılan bir çalışmanın sonuçları ile bu çalışmanın internet gazeteleri sayfalarındaki bulgular karşılaştırıldığında haber ve fotoğraf sayıları kapsamında aşağıdaki sonuçlara ulaşılır. Gazeteler arasında en çok haber Star'da (120) yer almakta, onu 100'ün üzerinde haber sayılarıyla Hürriyet (105), Cumhuriyet (103) ve Akşam (100) izlemektedir.

Basılı Gazetelerde Kullanılan Fotoğraf Sayısı: En çok fotoğraf kullanan ilk beş gazete, Star (136), Hürriyet (130), Takvim (119), Vatan (103), Posta (102). Spor hariç en çok renkli fotoğraf Hürriyet gazetesinde yer almaktadır. (105) (\%98). 
Star Gazetesi: Gazetede, (54-71) 61'i (\%45) spor konulu olmak üzere, toplam (107-169) 136 fotoğraf yayımlanmaktadır. Spor dışındaki (50-98) 75 (\%55) fotoğrafın (37-65) 52’si (\%69) renkli, (13-33) 23'ü (\%31) siyah-beyazdır.

Hürriyet Gazetesi: Gazetede, (19-26) 23'ü (\%18) spor konulu olmak üzere toplam (123-133) 130 fotoğraf yayımlanmaktadır. Spor dışındaki (99-114) 107 (\%82) fotoğrafin (99-110) 105’i (\%98) renkli, (1-5) 2'si (\%2) siyah-beyazdır.

Takvim Gazetesi: Gazetede, (44-61), 51'i (\%43) spor konulu olmak üzere, toplam (97-159) 119 fotoğraf yayımlanmaktadır. Spor dışındaki (40-88) 68 (\%57) fotoğrafin (27-55) 52'si (\%76) renkli, (3-23) 16's1 (\%24) siyah-beyazdır.

Vatan Gazetesi: Gazetede, (24-31) 27'si (\%26) spor konulu olmak üzere toplam 103 (97$108)$ fotoğraf yayımlanmaktadır. Spor dışındaki (73-80) 76 (\%74) fotoğrafın (55-61) 58'i (\%76) renkli, (16-21) 18'i (\%24) siyah-beyazdır.

Posta Gazetesi: Gazetede (12-19) 15’i (\%15) spor konulu olmak üzere toplam (92-111) 102 fotoğraf yayımlanmaktadır. Spor dışındaki (81-93) 87 (\%85) fotoğrafın (49-63) 52'si (\%60) renkli, (21-41) 35’i (\%40) siyah-beyazdır. Diğer gazetelerdeki fotoğraf kullanımlarına örnek olarak;

Cumhuriyet Gazetesi'nde, (7-9) 8'i (\%13) spor konulu olmak üzere toplam (57-62) 61 fotoğraf yayımlanmaktadır. Spor dışındaki (50-54) 53 (\%87) fotoğrafın (3-6) 5’i (\%9) renkli, (44-50) 48'i (\%91) siyah-beyazdır.

Zaman Gazetesi'nde, (20-22) 20'si (\%34) spor konulu olmak üzere toplam (57-60) 58 fotoğraf yayımlanmaktadır. Spor dışındaki (35-38) 38 (\%66) fotoğrafın (9-11) 10’u (\%26) renkli, (26-29) 28'si (\%74) siyah-beyazdır.

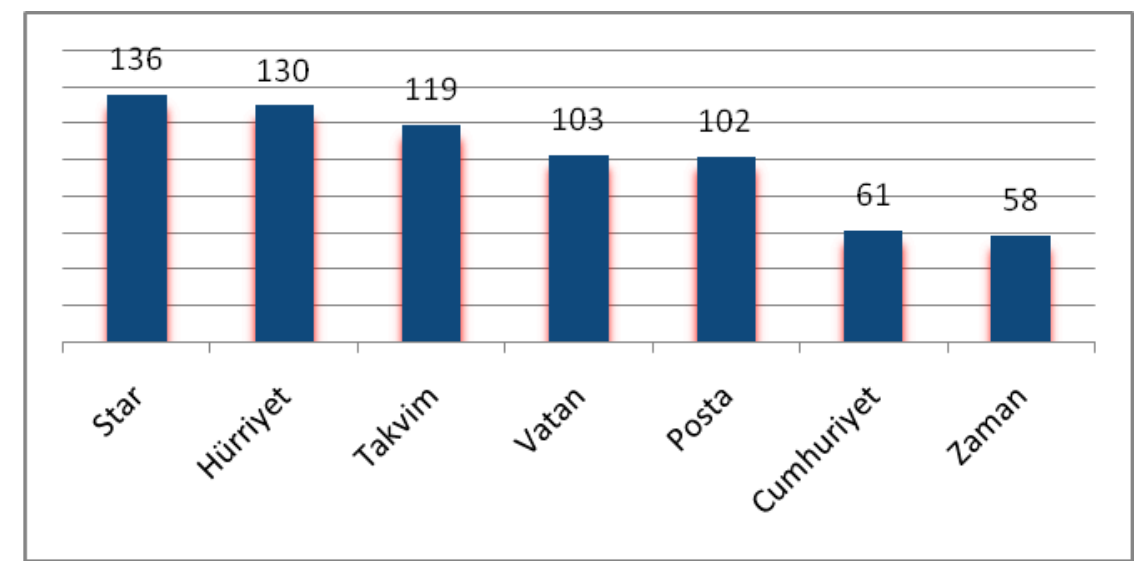

Grafik 1. Basılı Gazetelerde Fotoğraf Kullanımı

\section{Görüntü çözümlemesi ve eleştirisine örnek: "Gazetelerin internet ana sayfaları"}

Star Gazetesi: Star gazetesinin ana sayfası, üçlü bir haber anonsları bölümü ve gündemi belirleyen haber listeleriyle başlar. Günlük haber listesi, tıklama ile değişen yedi adet fotoğraflı haberden oluşur. Dikey olarak yerleştirilen haber listesinin başlıklarının açılış sayfasının tam ortasına yerleştirilmesi nedeniyle fotoğrafı yardımcı öğe olarak kullanan, yazıyı ön plana çıkaran, kolay okunan bir sayfa görünümündedir. Açılış sayfası ilk planında 10 adet fotoğraf dahil $\mathbf{1 7}$ fotoğraf görülmekte, fotoğrafların ayrımı çerçeveler yerine boşluklar kullanılarak yapılmaktadır. Logoda ve ana başlıklarda mavi rengin kullanılması, okumay1 rahatlatan beyaz renkli zemin kullanılması başlıca görsel unsurlardandır. Sitenin açılış sayfasında hiç reklam fotoğrafı ya da anonsu kullanılmaması ayrıştırıcı diğer özelliğidir. Genel olarak sayfada haber içerikli fotoğraf kullanıldığı, yazı ve görsel unsurların dengeli bir biçimde birbirini tamamladığı söylenebilir.

Hürriyet Gazetesi: Ana sayfa kırmızı bant üzerinde tasarlanan Hürriyet logosu ile açılıyor, altında üç adet fotoğraflı haber başlığı yer alıyor. Günlük haber listesi yatay olarak 
yerleştirilen 12 fotoğraflı, tıklama ile açılan tasarıma sahip. Başlıklar haber fotoğraflarının üzerine gömülerek tasarlandığı, yazı ile görselin tam bir ayrımı yapılmadığı görülüyor. Açılış sayfasında haber listesinin fotoğraflarıyla birlikte toplam 25 adet fotoğrafın bulunduğu, bunların iki tanesinin reklam fotoğrafı olduğu dikkat çekiyor. Sayfada kırmızı ve beyaz renklerin hakim olduğu bir tasarım kullanılırken, yeterince boşluk bulunmaması ve fazla sayıda görsel unsura yer verilmesi algılamayı güçleştiriyor. Ayrıca sayfanın sağ bölümüne dikey olarak yerleştirilen, içeriği değişen, hareketli reklam görselleri okuyucunun en fazla dikkatini çeken, haberlerin önüne geçen unsurlar.

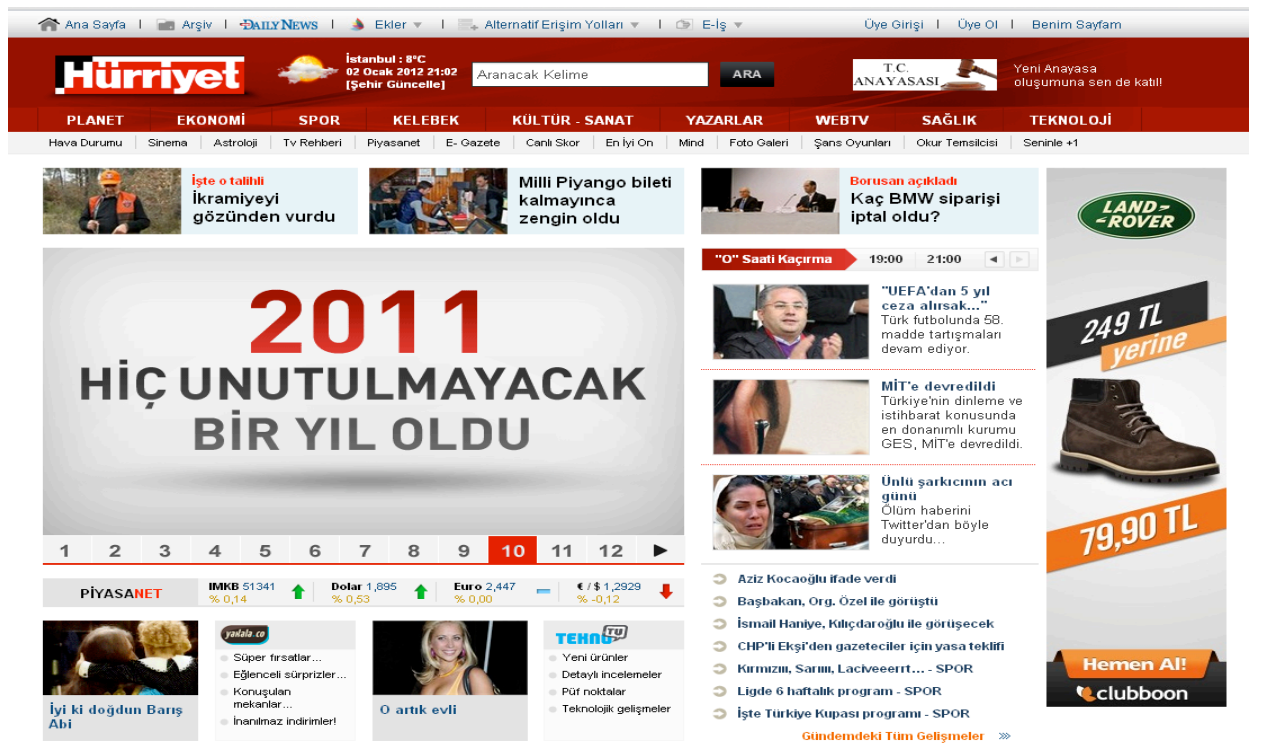

Şekil 1 Hürriyet Gazetesi İnternet Ana Sayfası

Takvim Gazetesi: İnternet ana sayfası diğerlerinden farklı olarak logo ile birleşen bir reklam görüntüsüyle açılıyor. Logonun altında üç adet haber başlığı ve fotoğraflı haber listelerinden oluşan bölüm yer alıyor. Sayfanın dikkat çeken özelliği iki farklı haber listesinin bulunması. Birincisi 12 fotoğraflı unsurdan oluşan ana haber listesi, diğeri yedi fotoğraflı haber listesi. Böylece sayfa toplamında $\mathbf{2 8}$ fotoğraf görülürken, bunlardan iki tanesinin reklam fotoğrafı olduğu görülüyor. Haber listeleri üzerine tıklanmadan otomatik olarak değişen özellik taşıyor. Beyaz zemin üzerine mavi rengin ağırlıklı olarak kullanıldığı sayfanın fotoğrafları çerçevelendirilerek ayrılan bir tasarıma sahip. Bir gazete sayfası olarak önemli yazı ve fotoğrafların öne çıkarıldığı bir sayfa olmak yerine dört adet görsel unsurun sürekli değişerek hareket etmesiyle okunması, algılanması ve anlaşılması çok zor, karmaşık, okuyucuyu yoran bir sayfa özelliği taşıdığı söylenebilir.

Vatan Gazetesi: Gazetenin internet ana sayfası gündemi oluşturan 12 adet haber listesiyle açılmaktadır. Bu liste "tüm manşetler" başlığı ile biterken bu bölüm tıklandığında bütün haberlerin başlık ve fotoğraf olarak aynı sayfada sıralandığı görülmektedir. Yatay olarak yerleştirilen 12 haberden bir tanesinin haberler arasına yerleştirilen reklam fotoğrafi olduğu dikkat çekmektedir. Bu haber listesinin üstünde siyah çerçeve içinde fotoğraflı olarak yatay üç adet haber kullanılmaktadır. Gazete logo satırı ile aynı hizada bir adet reklam fotoğrafı vardır; ancak haberlerin önüne geçtiğini söyleyemeyiz. Haber listesi dahil $\mathbf{2 1}$ fotoğraf ve başlıkların kullanımı yazının ikinci planda kaldı̆̆ olarak tasarlanmıştır. Sayfanın aşağı olarak devam eden diğer haberlerinde fotoğrafların öne çıktığı yazının az ya da sadece başlık olarak tercih edildiği görülmektedir.

Posta Gazetesi: Gazete diğer gazetelerle benzer biçimde 10 adet haber listesiyle internet gündemini oluşturmaktadır. Başlıklar haber fotoğraflarından herhangi bir çerçeveyle ayrılmadan üzerine gömülerek verilmektedir. Bu haber listesi arasında reklamların da olduğu dikkat çekicidir, böylece okuyucu haber ile reklamı aynı anda algılamaktadır. Günlük haber 
listesinin üstünde basılı gazetelerde sürmanşet olarak adlandırılan uygulamaya benzer biçimde üç adet fotoğraflı haber kullanılmaktadır. Ancak bunlar gündemin en önemli haberleri olarak değil cinsel içerikli olan ve sansasyon amaçlı olarak yorumlanabilecek, "Grup seksli fuhuşa suçüstü”, "Hiç erkek erkeğe birlikte oldunuz mu?" örnekli haberlerdir. Gazetenin internet sayfasındaki $\mathbf{2 4}$ fotoğraf ve diğer haberler basılı gazete örneklerine uygun biçimde birbirinden ayrılan başılı, siyah çerçeveli fotoğraf ve metin sıralamasıyla beyaz fon üzerinde verilmektedir.

Zaman Gazetesi: Gazetenin internet sayfasında fotoğrafın yazıya göre tercih edildiği görülmektedir. Ana sayfa yatay olarak yerleştirilen 15 adet günlük haber "Tüm manşetler" başlığı ile fotoğraflı olarak açılırken, logonun yanında iki fotoğraf bulunmaktadır. Gazete böylece manşet kavramını da alışılagelen kullanımından farklı olarak yeniden yorumlamaktadır. Buradaki 10 fotoğraf belli bir önem sırası amaçlanmadan otomatik olarak değişmektedir. Yatay kullanım olumlu anlamda dinlenme ve huzuru, olumsuz anlamıyla ölümü çağrıştırdığından, sayfanın ağırlıklı olarak yatay unsurlardan oluşması gazete sayfa tasarımı için uygun görülmeyebilir.

Ana sayfada aşağı doğru sıralanan küçük boyutlu fotoğraflarla birlikte $\mathbf{3 0}$ kadar görsel yer almaktadır. Ana sayfanın üç tarafı bazıları hareketli reklam fotoğrafları ile çevrilidir. $\mathrm{Bu}$ durum sayfadaki bütün haberlerin ve fotoğrafların bu çerçevede algılanmasını zorunlu kılmaktadır. Gündem haberlerinin yanında bulunan sayfanın tek haber listesi de reklam fotoğrafi etkisiyle güçlükle açılmaktadır. Sayfadaki gündemi oluşturan en önemli haberlerdeki fotoğrafların kullanımında yazının ikinci planda kaldığı, görselliğin öne çıktığı görülmektedir. Başlıkların fotoğraflara üzerine gömüldüğ̈ bu sayfa tasarımında önce fotoğraflar algılanmakta; başlıklar adeta fotoğraf altı yazısı gibi kullanılmaktadır. Sayfa tasarımında genel olarak kullanılan renkli fonlar ile fotoğraflar öne çıkmakta, yazının önüne geçmektedir. Sayfanın beyaz fon üzerine kurulan tasarımı hareketli reklam fotoğraflarının etkisiyle okuyucunun kolay algılamasını engeller niteliktedir.

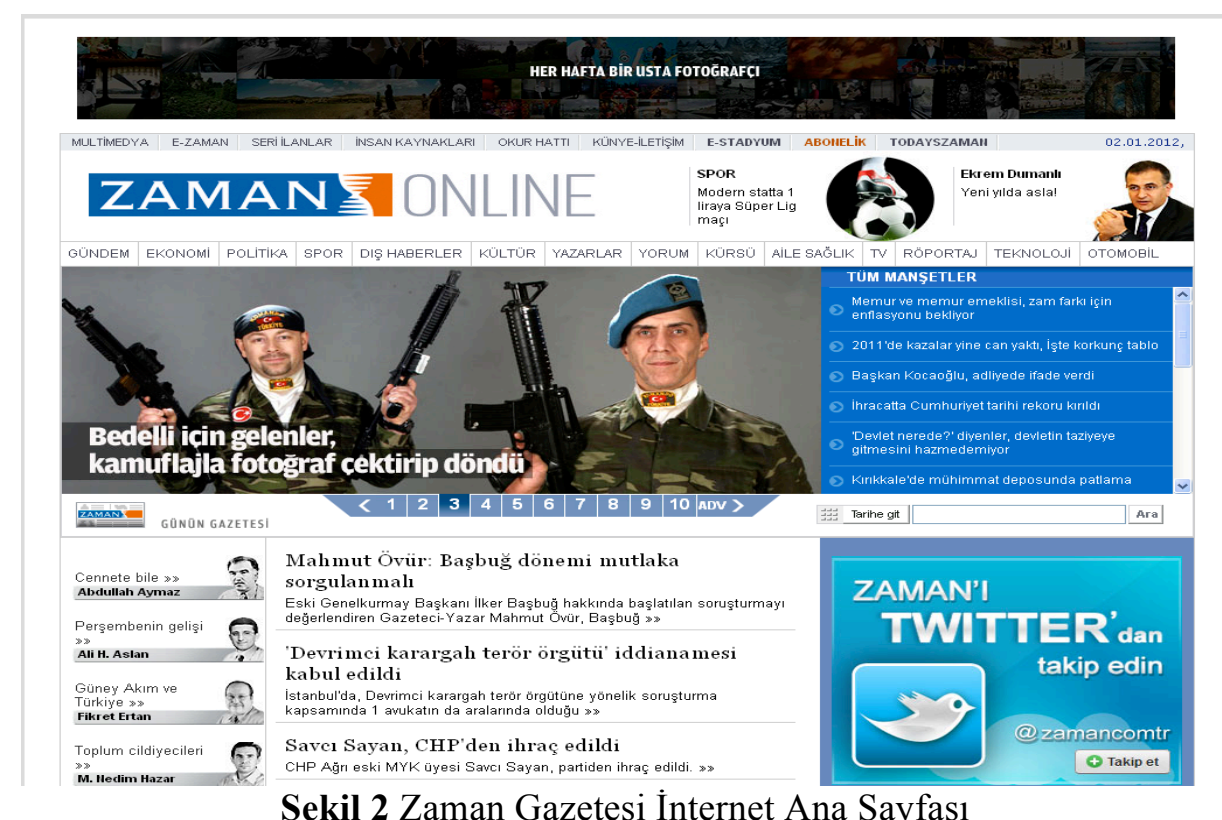

Cumhuriyet Gazetesi: Gazete ana sayfası gündemi oluşturan en önemli haberleri dikey olarak sıralanan altı adet fotoğraf listesiyle sunmaktadır. Bu fotoğraflardan birinci olan gündemin manşet haberi olarak sabit durmakta, altında bulunan başlık ayrı bir çerçeve ile fotoğraftan ayrılmaktadır. Basılı gazetenin birinci sayfasındaki manşet haberi ve fotoğrafının da bununla aynı olduğu görülmektedir. Tasarımda dikey unsurlar durağanlığa, saygınlığa ve güce göndermede bulunur. 


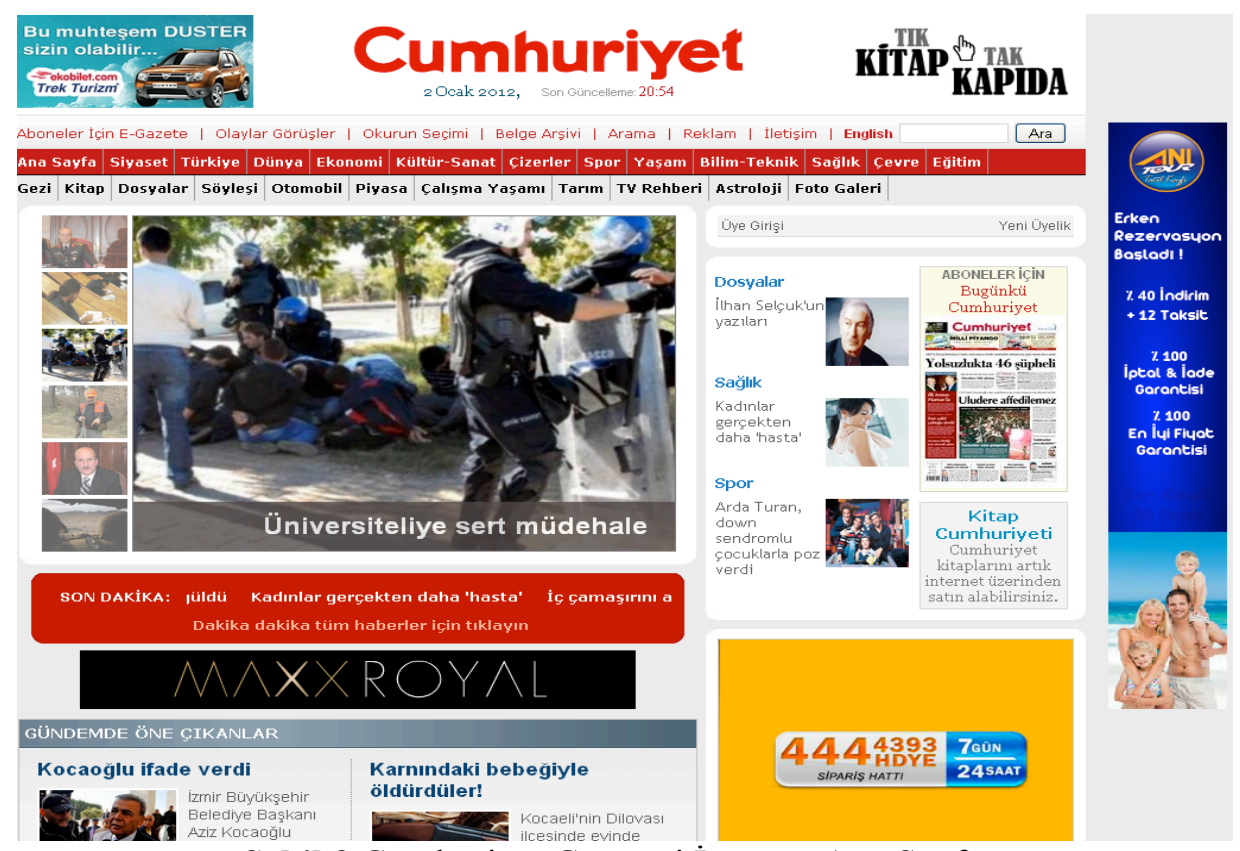

Şekil 3 Cumhuriyet Gazetesi İnternet Ana Sayfası

Ayrıca bu altı adet fotoğrafin algılamayı kolaylaştırıcı beyaz çerçeve ile birbirlerinden ayrıldığı dikkat çekmektedir. Günlük fotoğraflı haber listesinin altında sadece yazıdan oluşan bir haber listesi bulunmaktadır. Sayfada yazı ve fotoğraf dengesine özen gösterilen bir tasarım yapılmışıtır. Sayfa beyaz fon üzerine tasarlanmış, başlıklar ve yazılarda kırmızı, mavi ve beyaz renkler kullanılmıştır. Bu renk kullanımı yine basılı gazetenin renklerine sadık kalınarak yapılmış; okuyucunun basılı gazete alışkanlıkları dikkate alınmıştır. Sayfanın altındaki diğer haberlerde de basılı gazete tasarımında olduğu gibi başlık, 15 fotoğraf ve metin ayrımının boşluklar verilerek yapıldığı, fotoğrafların tek başına algılanmasına firsat verilmediği görülmektedir.

\section{SONUÇ}

Basılı gazetelerde fotoğraf kullanımı ile gazetelerin internet sayfalarında fotoğraf kullanımı arasında belirgin farklar görülür. Grafik 1'e göre, basılı gazetelerde en çok fotoğraf kullanan gazete Star (136) olurken, aynı gazete Grafik 2'ye göre internette en az fotoğraf kullanan ikinci gazete konumundadır. Hürriyet basında çok fotoğraf kullanan gazete olma geleneğine uygun olarak bu durumu internet sayfalarında da devam ettirir, en çok fotoğraf kullanan üçüncü gazete olur.

Basılı gazetelerin fotoğraf kullanımı ile internet sayfalarında fotoğraf kullanımı karşılaştırıldığında en büyük farklılık Zaman gazetesinde görülür. Basılan Zaman'da 58 adet ile en az fotoğraf kullanan gazete olurken, internet gazetesi 30 adet fotoğraf kullanımı ile ana sayfasında en fazla fotoğraf kullanılan gazete olur. Bu aynı zamanda gazete de fotoğrafın yazıya tercih edildiğinin önemli bir göstergesidir.

Gazetelerin internet sayfalarında genel olarak 15-30 fotoğraf kullanılır. Bunların arasında az da olsa reklam fotoğrafı da bulunur. İnternet sayfalarında fotoğrafın öne çıkarıldığı, yazının arka planda kaldığı bir tasarım görülür. 


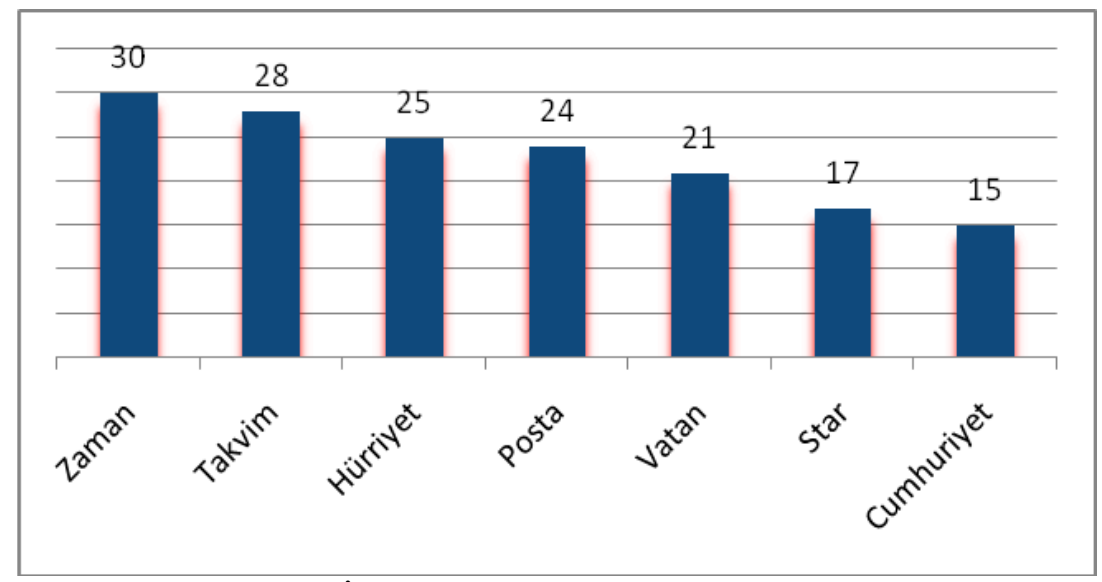

Grafik 2 İnternet Ana Sayfalarında Fotoğraf Kullanımı

Renk kullanımı açısından beyaz-kırmızı ve kırmızı-mavi karşıtlığını vurgulayan kullanımlar yoğundur. Fotoğrafa anlam kazandıran çerçeveleme ve boşluk kullanımı gazetelerde farklılık gösterir. Genel olarak ayrım boşluklarla yapılır. Yazının öne çıkarılmasını sağlayan tek başına kullanım Cumhuriyet gibi bazı gazetelerde azınlıkta kalır. Haberlerin liste olarak sunumunda olumsuzluk etkisi vermesine rağmen, yatay liste kullanımı yaygındır. Bu listeleme ile fotoğraf kullanım özelliğinin Türkiye çıkışlı gazetelerde yaygın olduğu, New York Times, The Times, Le Monde, Financial Times, The New Yorker, Pravda, China News Digest, Inside China Today, Sngtao, Asahi Shimbun, The Japan Times ve Osaka Shimbun gibi yabanc1 gazetelerde tercih edilmediği, yabancı gazetelerin daha çok tek fotoğraflı manşet haber tasarımını tercih ettikleri görülmektedir. Ayrıca renklerin kullanımı logo ve başlık gibi bazı içeriklerin öne çıkmasına haber metinleri gibi bazı metinlerin de geriye atılmasına neden olur. Fotoğraf kullanımındaki bir başka ayrıntı ise basılı gazetelerin tersine fotoğrafı çeken muhabirin imzası bulunmamasidır.

\section{KAYNAKLAR}

Barthes, R.(2009). Göstergebilimsel Serüven, İstanbul: YKY.

Derman, İ.(1991). Fotoğraf ve Gerçekçilik, İstanbul: Ağaç Yayıncılık.

Gezgin, S.(1994). Basında Fotoğrafçı1lı, İstanbul: Der Yayınları.

Girgin, A.(2003). "Yaygın (Ulusal) Basında Haber, Fotoğraf Sayıları ve Konuları Üzerine Bir Araştırma" Available at http://atillagirgin.net/makaleler/makale ana.htm [13.10.2011].

İnceoğlu, Y. G. ve Çomak, N. A.(2009). Metin Çözümlemeleri, İstanbul: Ayrıntı Yayınları.

Ketenci,H. F. ve Bilgili C.(2006). Yongaların 10000 Yıllık Gizemli Dansı-Görsel

İletişim\&Grafik Tasarımı, İstanbul: Beta.

Sontag, S.(2008). Fotoğraf Üzerine, İstanbul: Agora Kitaplığı.

Terzi, M. U.(2006), "Fotoğraf Okuma ve Eleştiri”, Marmara Üniversitesi, Güzel Sanatlar

Enstitüsü, Yayınlanmamış Yüksel Lisans Tezi.

Cumhuriyet Gazetesi http://www.cumhuriyet.com.tr/ [19. 12. 2011].

Hürriyet Gazetesi http://www.hurriyet.com.tr/anasayfa// [18.12.2011].

Posta Gazetesi http://www.posta.com.tr/ [17.12.2011].

Star Gazetesi http://www.stargazete.com/ [18.12.2011].

Takvim Gazetesi http://www.takvim.com.tr/ [19.12.2011].

Vatan Gazetesi http://www.gazetevatan.com/root.ast (18.12.2011].

Zaman Gazetesi http://www.zaman.com.tr/ [19.12. 2011].

http://www.ozgur-gundem.com/ [14.12.2011].

http://www.gazeteciler.com/gazete-tirajlari.html [17.12.2011]. 